\title{
A review of therapeutic effects of mesenchymal stem cell secretions and induction of secretory modification by different culture methods
}

\author{
Marialaura Madrigal ${ }^{1,2,3^{*}+}$, Kosagisharaf S Rao ${ }^{2}$ and Neil H Riordan ${ }^{3+}$
}

\begin{abstract}
The mesenchymal stem cell (MSC) is being broadly studied in clinical trials. Contrary to the early paradigm of cell replacement and differentiation as a therapeutic mechanism of action, evidence is mounting that the secretions of the cells are responsible for their therapeutic effects. These secretions include molecules and extracellular vesicles that have both local and distant effects. This review summarizes the up- and down-regulation of MSC anti-inflammatory, immune modulating, anti-tumor, and regenerative secretions resulting from different stimuli including: a) hypoxia, which increases the production of growth factors and anti-inflammatory molecules; b) pro-inflammatory stimuli that induce the secretion of immune modulating and anti-inflammatory factors; and c) 3 dimensional growth which up regulates the production of anti-cancer factors and anti-inflammatory molecules compared to monolayer culture. Finally we review in detail the most important factors present in conditioned medium of MSC that can be considered protagonists of MSC physiological effects including HGF, TGF-b, VEGF, TSG-6, PGE2 and galectins 1, and 9. We conclude that there is potential for the development of acellular therapeutic interventions for autoimmune, inflammatory, and malignant diseases and tissue regeneration from cellular secretions derived from MSCs cultured under the appropriate conditions.
\end{abstract}

Keywords: MSC, Hypoxia, Inflammation, Spheroids, VEGF, PGE2, TSG-6, Cell therapy, Conditioned media

\section{Introduction}

Mesenchymal stem cells (MSCs) are classically defined as adherent, non-hematopoietic cells expressing the surface markers CD90, CD105, and CD73, and lacking the expression of CD14, CD34, and CD45. The cells also have the capacity to differentiate into adipocytes, chondrocytes, and osteocytes in vitro after treatment with differentiation inducing agents [1]. Although early studies in the late 1960s initially identified MSCs in the bone marrow [2], more recent studies have reported these cells can be purified from various tissues such as adipose [3], heart [4], Wharton's jelly [5], dental pulp [6] peripheral blood [7], cord blood [8], and more recently menstrual blood [9-11] and chorionic villi [12]. Studies of bone marrow showed that although MSC are the primary cell type that

\footnotetext{
* Correspondence: marialauramadrigal@medistemresearch.com

${ }^{\dagger}$ Equal contributors

1 Department of Biotechnology, Acharya Nagarjuna University, Guntur, India

${ }^{2}$ INDICASAT-AIP, City of Knowledge, Republic of Panama

Full list of author information is available at the end of the article
}

overgrow in vitro cultures, in vivo MSC are found at a low ratio compared to other bone marrow mononuclear cells, specifically, $1: 10,000$ to $1: 100,000$ [13]. The physiological role of MSC still remains to be fully elucidated, with one hypothesis being that bone marrow MSC act as precursors for stromal cells that make up the hematopoietic stem cell microenvironment [14-16].

The first clinical use of MSCs was to accelerate hematopoietic recovery after bone marrow ablation in the context of post chemotherapy hematopoietic stem cell transplant. Lazarus et al. report of the use of autologous, 1-50 × $10^{6}$ cells in vitro expanded, "mesenchymal progenitor cells" to treat 15 patients suffering from hematological malignancies in remission and treatment showed no treatment-associated adverse effects [17]. In a subsequent study by the same group, MSC treatment accelerated hematopoietic reconstitution in 28 breast cancer patients who received high dose chemotherapy with no reported treatment associated adverse effects. The authors noted that leukocytic and thrombocytic reconstitution 
occurred at an accelerated rate as compared to historical controls [18]. In addition to feasibility, these studies importantly established techniques for ex vivo expansion and administration.

Demonstration of clinical feasibility and multiple animal models providing rationale for therapeutic efficacy of MSCs in non-hematopoietic indications [19-26], gave rise to a series of clinical trials of MSCs in a wide range of major diseases including stroke [27-30], heart failure [31,32], COPD [33] and liver failure [34]. Rare diseases treated with MSCs such as osteogenesis imperfecta [35], Hurler syndrome [36], and Duchenne Muscular Dystrophy [37] have also been reported.

The ability to generate clinically significant numbers of well-defined MSCs starting with small clinical samples, feasible administration without the need for haplotype matching, and excellent safety profile of the cells has resulted in a broad interest in the clinical use of MSCs. 402 clinical trials testing MSC are currently listed on the international registry www.clinicaltrials.gov. While some trials have demonstrated efficacy of MSC, full elucidation of mechanisms of action is lacking. Initial studies demonstrated the ability of certain MSC types to differentiate into functional tissues that is compromised as a result of the underlying pathological. In spite of the capacity of MSCs to differentiate, evidence is mounting that much of the disease-modulating activity of MSCs is due to products secreted by the cells.

This paracrine effect was first observed in heart disease murine models, in which it was found that bone marrow (BM) MSCs injected into infarcted hearts did not differentiate into cardiomyocytes under physiological in vivo conditions [38]. After intravenous injection the majority of administered MSCs lodge in lungs and liver with only a small minority entering the tissue of pathology [39]. Gnecchi hypothesized that clinical effects of MSCs are not due to cell differentiation, after observing re-establishment of cardiac function and prevention of ventricular remodeling in fewer than 72 hours post injection [40]. The same group went on to show that MSC conditioned medium alone enhanced recovery of ischemic cardiomyocytes in vitro [41]. Similarly Lee and colleagues showed an anti-inflammatory effect and cardiac infarct size reduction; in spite of the fact that the majority of the intravenously infused MSCs (human MSCs in mouse model) were found as emboli in lungs and few cells migrated to other tissues including the infarcted heart [42]. Shabbir et al. demonstrated increased fractional shortening, and capillary and myocyte density, as well as attenuated myocyte apoptosis and fibrosis; in a hamster model of heart failure, in which MSCs were injected intramuscularly. They also showed that intramuscular injection of cell free MSC conditioned medium similarly rescued the failing heart in the same model [43].
Another example of what could be considered purely the effect of the MSC secretion was demonstrated in a rat model of complete transection of the spinal cord in which the termini of the cut cord were covered with fibrin glue containing human umbilical cord MSCs. The intervention improved the locomotion and resulted in regeneration of the spinal cord. It was found that human MSC antigen did not overlap with the staining for neurons, oligodendrocytes or astrocytes, demonstrating that there was a mechanism other than MSC differentiation involved in the spine cord lesion recovery [44]. Recently, Song et al., used a rat model of overactive bladder and demonstrated that MSC hardly engraft into damaged bladders, but increased stem cell gene expression suggesting an MSC paracrine effect is related to unleashing/mobilizing primitive progenitor cells as a possible mechanism for the long-term/stable therapeutic efficacy of MSCs [45].

The above-mentioned studies suggest that MSC efficacy may be mediated primarily by secreted factors. Identification of secreted factors will result in a better understanding of MSC therapeutic activity, which would allow not only for generation of MSCs optimized for efficacy for a potential target, but also the possibility of administering secreted factors that are naturally or synthetically generated as an alternative to use of live cells. There are a multitude of culture conditions that allow MSC to produce differing sets of trophic factors under biological need to be explored. In this paper, we will review MSC secreted factors including molecules and extracellular vesicles (exosomes and microvesicles) and culture conditions which can enhance the in vitro production of those secreted factors.

\section{MSC therapeutic activity is stimulated by physiological need}

MSCs in standard monolayer culture secrete cytokines, micro RNA (miRNA), exosomes and microvesicles as a matter of course. The concept that MSC act as "repair cells" of the body would imply that MSC do not only constitutively secrete regenerative factors, but also produce some factors in response to stimuli. Responsive production and secretion is an experimental reality. Hypoxic preconditioning, addition of an inflammatory stimuli, and growing cells in spheres or tri-dimensional scaffolds have all been shown to modulate the production and excretion of different potential therapeutic factors. A summary of the effects of culture conditions on up-regulation of molecular secretion by MSCs and the up- and down-regulation of effects of MSCs and conditioned medium can be found in Table 1 .

\section{MSC stimulation by hypoxia}

One of the most common elements of tissue injury is the presence of hypoxia. Interstitial damage is often 
Table 1 Summary of MSC secreted factors induced by Hypoxia, Inflammatory Stimuli and 3-dimensional culture conditions and their effect on other cells

\begin{tabular}{|c|c|c|c|}
\hline $\begin{array}{l}\text { Molecule of } \\
\text { interest }\end{array}$ & $\begin{array}{l}\text { Hypoxia } \\
\text { preconditioning } \\
\left(1-2 \% \mathrm{O}_{2}\right)\end{array}$ & $\begin{array}{l}\text { Inflammatory } \\
\text { stimuli (INF- } \gamma \text {, } \\
\text { TNF-a, LPS) }\end{array}$ & $\begin{array}{l}\text { 3D culture } \\
\text { configuration } \\
\text { (microcarriers, } \\
\text { microspheres) }\end{array}$ \\
\hline FGF & $\uparrow$ & & \\
\hline VEGF & $\uparrow$ & $\uparrow$ & \\
\hline IGF & $\uparrow$ & & \\
\hline HGF & $\uparrow$ & $\uparrow$ & \\
\hline IDO & $\uparrow$ & $\uparrow$ & \\
\hline Oct 4 & $\uparrow$ & & \\
\hline $\operatorname{Rex} 1$ & $\uparrow$ & & \\
\hline TGF- $\beta$ & & $\uparrow$ & \\
\hline PGE2 & & $\uparrow$ & $\uparrow$ \\
\hline BMP2 & & $\uparrow$ & \\
\hline Factor $\mathrm{H}$ & & $\uparrow$ & \\
\hline Gal-9 & & $\uparrow$ & \\
\hline TSG-6 & & & $\uparrow$ \\
\hline STC-1 & & & $\uparrow$ \\
\hline CXCR4 & & & $\uparrow$ \\
\hline TRAIL & & & $\uparrow$ \\
\hline IL-24 & & & $\uparrow$ \\
\hline CD82 & & & $\uparrow$ \\
\hline $\begin{array}{l}\text { Secretion of } \\
\text { microvesicles/ } \\
\text { exosomes }\end{array}$ & & $\uparrow$ & \\
\hline \multicolumn{4}{|c|}{ MSC or MSC-CM effect on other cells } \\
\hline CXCL2 & & & $\downarrow$ \\
\hline TNF-a & & & $\downarrow$ \\
\hline IL-6 & & & $\downarrow$ \\
\hline IL12p40 & & & $\downarrow$ \\
\hline IL23 & & & $\downarrow$ \\
\hline $\begin{array}{l}\text { T-cell } \\
\text { proliferation }\end{array}$ & $\downarrow$ & $\downarrow$ & \\
\hline CD31+ & $\uparrow$ & & \\
\hline aSMA + desmin+ & $\uparrow$ & & \\
\hline
\end{tabular}

$\uparrow=$ upregulated or stimulated; $\downarrow=$ down-regulated or non-stimulated.

associated with activation of the coagulation cascade, resulting in areas of hypoxia. It is known that reduction in oxygen tension in a variety of tissues leads to activation of the hypoxia inducible factor (HIF-1 $\alpha$ ), which induces transcription of angiogenic genes such as vascular endothelial growth factor (VEGF) [46-49], as well as the MSC chemoattractant stromal cell-derived factor 1 (SDF-1) [50,51]. Once MSC migrate to areas of hypoxia, it has been demonstrated that production of various therapeutic paracrine mediators is increased. Several groups have demonstrated the relevance of hypoxia to
MSC growth factor production in vitro. For example, exposure of bone marrow (BM)-MSC to 24 hours of hypoxia (1\% oxygen) resulted in marked induction of VEGF, Fibroblast growth factor 2 (FGF-2), Hepatocyte growth factor (HGF), and Insuline like growth factor 1 (IGF-1) production, in an NF-kappa $\beta$ dependent manner [52]. The stimulation of growth factor production by hypoxia is not specific to BM-MSC and has been demonstrated in MSC derived from adipose tissue [53], placenta [54], and dental pulp [55]. Furthermore, hypoxia stimulation of angiogenic and anti-apoptotic factors such as VEGF, FGF-2, HGF and IGF-1 has been reported to also occur in MSC from aged animals, supporting clinical utility [56]

The biological relevance of MSC-secreted growth factors stimulated by hypoxia can be seen in studies showing that conditioned media from MSCs grown under hypoxic but not normoxic conditions endow therapeutic benefit in animal models. For example, Chang et al. demonstrated that conditioned medium from hypoxia treated BM-MSC was capable of restoring neurological function in a rat model of traumatic brain injury significantly better than administration of conditioned medium from normoxia conditioned BM-MSC. Furthermore, they demonstrated that efficacy was associated with production of HGF and VEGF, which were involved in the induction of endogenous neurogenesis [57]. In a similar study, the therapeutic activity of hypoxic and normoxic conditioned BM-MSCs was compared in a rat massive hepatectomy model. Hypoxic conditioned BM-MSCs produced significantly higher levels of VEGF in vitro as compared to control treated cells. Furthermore, in vivo administration resulted in significantly elevated cyclin D1, proliferating cell nuclear antigen-positive hepatocytes, liver weight/body weight ratio, and survival compared with animals that received normoxia preconditioned BM-MSC. Interestingly, blockade of VEGF by in vivo administration of anti-VEGF antibody negated the therapeutic effect of hypoxia [58]. In a rat model of diabetic cardiomyopathy it was demonstrated that administration of hypoxia treated BM-MSC resulted in superior inhibition of pathological condition as compared to administration of control BM-MSC. The therapeutic effect was associated with protection of cardiomyocytes by increasing the activity of matrix metalloproteinase-2; inhibiting Transforming growth factor beta 1 (TGF- $\beta 1$ ) and caspase- 3 and, upregulating $\mathrm{Bcl}-2 /$ Bax ratio [59].

Hypoxia not only triggers production of growth factors from MSC, but also allows the MSC to retain an undifferentiated phenotype, allowing for self-renewal without differentiation. This may be due in part to the fact that anatomically, MSCs tend to be found in hypoxic areas of the body, i.e. adipose tissue and bone marrow are relatively poorly perfused by the circulatory system $[48,60]$. It was demonstrated in vitro that exposure of BM-MSCs 
to hypoxia results in augmented cellular proliferation and the formation of colonies in the colony-forming unit assay (CFU-A) and the expression of stemness markers Rex-1 and Oct-4, thereby suggesting an increase in the stemness of BM-MSC when exposed to hypoxia [49].

One of the key factors of MSC of relevance to therapeutics development is their known anti-inflammatory/ immune modulatory properties. The potency of this effect is seen in clinical studies showing efficacy of MSC at inhibiting lethal, immune-based condition of graft versus host disease [61-66]. Exposure of MSC to hypoxia has been shown in several systems to augment immune modulatory activity. In one example, MSC expression of the tryptophan catabolizing enzyme indolamine 2,3 deoxygenase (IDO) was markedly upregulated in the presence of hypoxia [67]. IDO is critical in immune regulation by MSC in part through induction of T cell anergy [68], and in part by stimulation of $\mathrm{T}$ regulatory cells (T-regs) $[69,70]$. The practical relevance of hypoxia-stimulated immune regulation of MSCs is seen in the situation of allogeneic use of BM-MSCs for stimulation of therapeutic angiogenesis. It was shown in a recent study that hypoxia-conditioned BM-MSCs from B6 mice ameliorate limb ischaemia of $\mathrm{Balb} / \mathrm{c}$ mice compared to normoxic MSCs. Histological staining demonstrated that hypoxic BM-MSC have an increased ability to engraft in allogeneic recipients by reducing natural killer cells (NK) cytotoxicity, and decrease the accumulation of host-derived NK cells when transplanted in vivo. These allogeneic hypoxia treated BM-MSCs gave rise to CD31+ endothelial cells and $\alpha \mathrm{SMA}+$ and desmin + muscle cells, thereby enhancing angiogenesis and restoring muscle structure. Moreover, application of anti-NK antibodies together with normoxic MSCs enhanced angiogenesis and prevented limb amputation in allogeneic recipients with limb ischemia, thus demonstrating that the benefit of hypoxic conditioning was mediated by enhanced immune modulation in the allogenic setting [71].

In short, hypoxic conditioning of cultured MSCs may result in increased production and secretion of trophic factors, augmentation of angiogenic effects, and enhanced immune modulating activity from the conditioned cells relative to normoxic culture conditioning.

\section{Inflammatory stimuli}

In addition to responding to hypoxia, MSC produce immune modulatory and regenerative factors in response to inflammatory stimuli. One of the most studied mechanisms by which inflammation triggers MSC activity is treatment with interferon gamma (IFN- $\gamma$ ). This cytokine is typically produced during inflammatory Th1 immune responses that are associated with autoimmunity mediated by cellular means, such as CD8 T cells and NK cells. Examples of conditions associated with this type of immune response include multiple sclerosis, diabetes type 1, and rheumatoid arthritis [72]. Exposure of MSC to INF- $\gamma$ has been demonstrated by numerous groups to increase the immune suppressive activity by stimulation of the enzyme IDO [73-76]. As expected, exposure to this inflammatory mediator induced production of other inhibitors of inflammation by MSCs, including the complement inhibitor Factor $H$ [77], as well as the immune modulatory molecules TGF- $\beta$ and HGF [78]. At a functional level, Noone et al. demonstrated that INF- $\gamma$ pretreatment of MSC resulted in protection of MSCs from NK-mediated killing in part through upregulation of prostaglandin E (PGE)-2 synthesis [79]. IFN- $\gamma$, but also tumor necrosis factor-alpha (TNF- $\alpha$ ), IL- $1 \alpha$, and IL-1 $\beta$ induce Gal-9 in MSC [80].

Another inflammatory mediator known to induce regenerative activities in MSC is the macrophage-derived cytokine TNF- $\alpha$. TNF- $\alpha$ pretreatment of MSCs endowed the cells with superior angiogenic activity in vitro, as assessed by expression of VEGF, as well as in vivo in an animal model of critical limb ischemia, as compared to untreated MSCs [81]. Another study demonstrated that TNF- $\alpha$ preconditioning increased proliferation, mobilization, and osteogenic differentiation of MSCs and up-regulated bone morphogenetic protein-2 (BMP-2) protein level. BMP-2 silencing by siRNA partially inhibited osteogenic differentiation of MSC induced by TNF- $\alpha$ [82]. More recent studies have shown that activators of innate immunity, such as lipopolysaccharide, and toll like receptor (TLR) agonists, also are capable of stimulating regenerative activity of MSCs through induction of production of paracrine factors such as VEGF [83]. IFN- $\gamma$ and TLR also up-regulate the glucocorticoids production which decreases T-cells stimulated by radiotherapy in colonic mucosa [84]. In general there is evidence to suggest that inflammatory stimuli enhance the regenerative potential and antiinflammatory response of MSCs.

\section{Tri-dimensional culture system activation}

MSC are most typically grown in vitro in monolayer systems in surface treated plastic flasks. Tridimensional configurations such as spheroid culture have been shown to stimulate higher levels of trophic factor secretion compared to monolayer culture. One of the first observations were that lung MSC micro-emboli of myocardial infarcted mice produced TNF-stimulated gene 6 protein (TSG-6) and found it to be an important anti-inflammatory factor that improved outcomes [42]; TSG-6 is not found in significant quantities in standard MSC monolayer culture. Bartosh et al. [85] found that hanging drop induced MSC spheres containing $25 \mathrm{~K}$ cell per drop produced significantly higher TSG-6 than monolayer cultures with production increasing over 4 days of culture. In addition, they found higher expression of the anti-inflammatory and antiapoptotic protein STC-1, CXCR4; and three 
anticancer proteins: TRAIL, IL-24 and CD82 in the MSC spheres.

Conditioned medium (CM) from human MSC spheroids inhibited production of TNF- $\alpha$, CXCL2, IL6, IL12p40, and IL23 from LPS stimulated macrophages, and presented higher production of prostaglandin E2 (PGE2). This anti-inflammatory and immune modulator is produced through a caspase-dependent IL-1 pathway [86,87]. Of relevancy is that therapeutically, spheroids and spheroid-derived cells were more effective antiinflammatory agents in a murine model of zymosaninduced peritonitis than monolayer MSC culture cells [85]. Further studies by the same group demonstrated that in vivo, intraperitoneal MSCs tended to self-aggregate resulting in self-activation of increased production of trophic factors [87].

Dynamic cultures using spinner flask or rotating wall vessel bioreactor have shown to form small spheroids and demonstrated better osteogenesis and adipogenesis differentiation characteristics, as well as higher concentration of IL-24 [88].

Overall, these data suggest that the paracrine effects of MSCs are inducible, and have a relationship with context-, or niche-specific settings (Figure 1).

\section{MSC produced biomolecules}

As described above, MSCs produce a plethora of biologically active molecules in response to various stimuli. In this section we will list some of the common molecules associated with MSC activity, and describe their biological significance.

\section{Hepatocyte Growth Factor (HGF-1)}

Originally discovered as a gene transcript associated with liver regeneration [89], HGF-1 is the high affinity ligand for the receptor tyrosine kinase Met, whose activation is associated with a variety of regenerative activities including angiogenesis, myogenesis, and hematopoiesis [90]. HGF-1 is secreted as a single inactive polypeptide and is cleaved by serine proteases into a 69-kDa alpha-chain and $34-\mathrm{kDa}$ beta-chain. A disulfide bond between the alpha and beta chains produces the active, heterodimeric molecule. The protein belongs to the plasminogen subfamily of S1 peptidases but has no detectable protease activity. Demonstration of regenerative activity by HGF-1 outside of the liver has been shown by experiments demonstrating involvement of this cytokine in acceleration of wound healing, including in cutaneous [91], corneal [92] and gastric [93] wounds. Other biological activities of HGF-1 include stimulation of angiogenesis, which was demonstrated by studies in which injection of HGF-1 plasmid resulted in limb salvage in animals [94], and humans $[95,96]$, in limbs with poor circulation. In line with other soluble factors associated with regenerative processes,
HGF-1 possesses immune modulatory activity. Treatment of dendritic cells with HGF-1 results in reduction of ability to induce generation of inflammatory Th1 cells, in part through blocking expression of co-stimulatory molecules such as CD80 and CD86 [97]. Furthermore, studies have shown that in vivo administration of HGF-1 protects against autoimmune disease such as experimental autoimmune encephalomyelitis, and collagen induced arthritis, through stimulation of T-regs producing the immune suppressive cytokine IL-10 $[98,99]$.

MSC production of HGF-1 has been shown to be critical in several in vivo therapeutic activities of MSCs. One example is in immune modulation associated with intravenous administration of MSCs in models of autoimmunity. Bai et al. demonstrated that administration of either MSCs or MSC conditioned medium were capable of suppressing progression, and inducing remission of disease pathology in the EAE model of multiple sclerosis. Serial sections of tissue from treated mice revealed high concentrations of HGF-1, which was also found in the conditioned media. Blocking antibodies to HGF-1 were demonstrated to negate the protective effects of MSCs or MSC conditioned media in this model [100]. Neuroprotective effects of MSC conditioned media also appeared to be dependent on HGF-1, based on experiments in which neutralization of HGF-1 resulted in loss of protection from apoptosis in a glutamate induced excitotoxicity model [101]. Suppression of apoptosis by HGF-1 was also demonstrated to be essential for the therapeutic effects of adipose derived MSCs in a rodent model of acute kidney failure induced by high dose cisplatin. Yasuda et al. [102], demonstrated that while local administration of adipose MSCs was capable of reducing acute tubular necrosis and loss of kidney function after cisplatin administration, these effects were negated by administration of anti-HGF-1 antibodies.

Thus the effects of HGF-1 generated by MSCs appear to be multifunctional, directed towards the combination of: angiogenesis; immune modulation; and protection from apoptosis.

\section{Transforming Growth Factor Beta (TGF- $\beta$ )}

TGF- $\beta$ is a protein generally known to possess autocrine inhibitory activities to non-malignant cells, and is widely expressed in a variety of tissues in a latent form [103]. TGF- $\beta$ signals through the SMAD family of intracellular proteins and its overexpression is associated with fibrotic disease [104]. Local production of TGF- $\beta$ is a potent mechanism of immune suppression in a variety of contexts including tumor [105,106], pregnancy [107], ocular [108], and testicular immune privilege [109]. Mechanistically, TGF- $\beta$ acts by suppressing dendritic cell maturation [110], stimulating T-regs production [111], and suppressing generation of inflammatory Th17 cells [112]. 


\section{a}

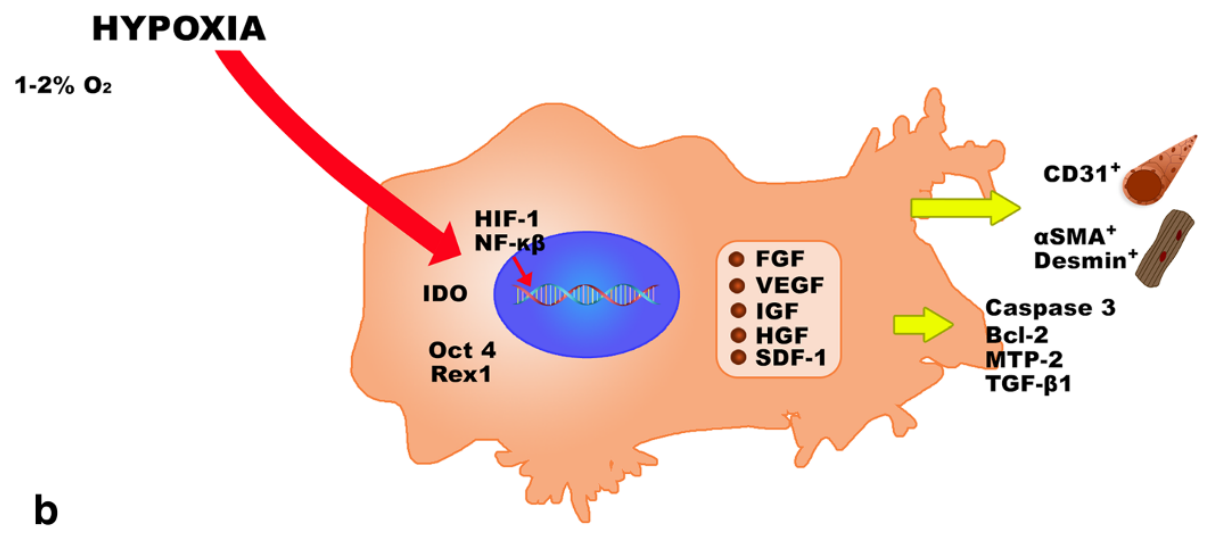

\section{INFLAMMATION}

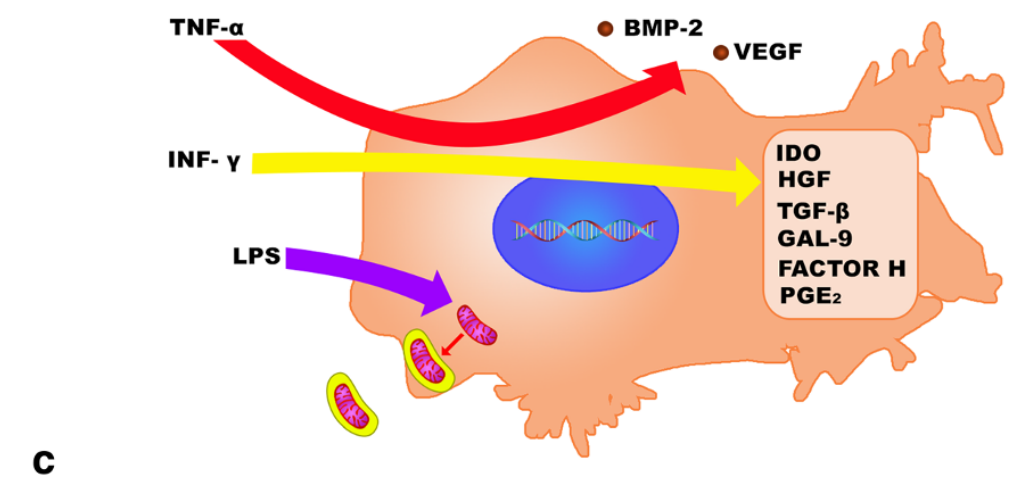

\section{D CULTURE METHODS}

\section{Microspheres Microcarriers}

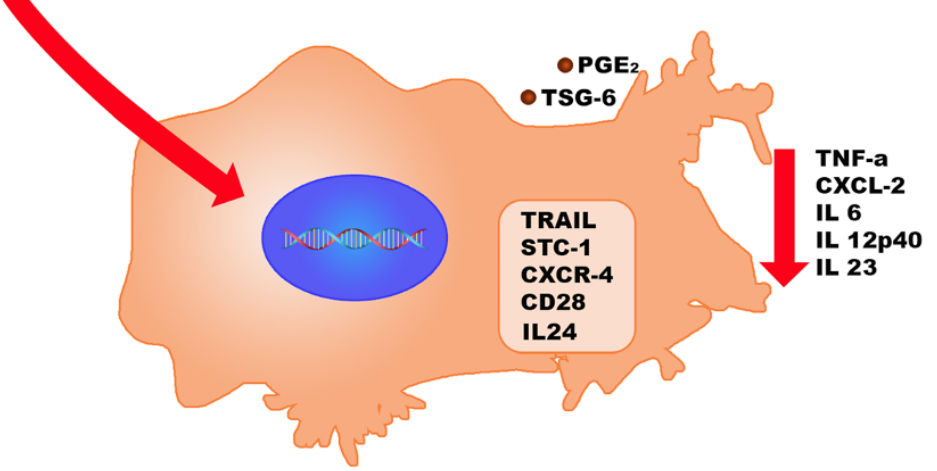

Figure 1 Effects of the hypoxia, inflammation, and 3D culture on MSC in terms of expression and secretion of molecules of interest for cell therapy. a) Hypoxia activates the HIF and the NF-kappa $\beta$; increases the expression of several growth factors (inside the square), it also induces IDO activity and enhances stemness (Oct- 4 and Rex-1). Also, the hypoxia pre-conditioned MSC, favor the activation of caspase 3, BCl-2, MTP-2, TGF- $\beta 1$ on target cells improving apoptosis resistance; improve regenerative capacity of muscle and endothelial cells. b) Inflammation induced by INF- $\gamma$ increases the expression of anti-inflammatory and regenerative molecules (in the square) and, through TNF-a enhances the production of VEGF and BMP-2 which favor formation of new vessels and osteoblasts respectively. Also MSC exposed to LPS are able to encapsulate mitochondria and deliver them to other cells. c) 3D culture methods such as microcarriers or spheroids induce the production of TSG-6 and increases PGE 2 secretion. Besides, it also favor the secretion of antiapoptotic and anticancer molecules (in the square). Further, MSCs obtained from 3D configurations, inhibit the expression of inflammatory and cancer related molecules in target cells.

MSC production of TGF- $\beta$ has been demonstrated in MSCs derived from numerous tissues including adipose [113], bone marrow [114], and umbilical cord [115]. The essential contribution of TGF- $\beta$ to suppression of T cell proliferation by MSC was originally demonstrated by Zhao et al. [116]. They showed that antibody neutralization resulted in restoration of lymphocyte proliferation. Subsequent studies have demonstrated that MSC 
administration to animals suffering ischemic injury to the CNS resulted in improved neurological outcomes, which was abrogated by silencing TGF- $\beta$ in the administered MSC [117]. The TGF- $\beta$ dependent therapeutic effects were associated with reduction of inflammatory cytokine expression in the CNS and suppression of microglial activation.

MSC-based immune modulation has been shown by several investigators to be mediated in part by TGF- $\beta$. Ye et al. utilized an in vitro model of T-regs generation to demonstrate that MSC-derived TGF-b is necessary for differentiation of FoxP3 expressing T-regs from naïve $\mathrm{T}$ cells in an antigen-nonspecific system [118]. In an in vivo study, administration of MSC into a bacteriallyinduced hepatic injury model was shown to result in alleviation of hepatotoxicity, mediated in part by TGF- $\beta$ dependent generation of T-regs [118].

Overall, the effects of TGF- $\beta$ production by MSC appear to relate primarily to immune modulation. Given the profibrotic role of TGF- $\beta$ in various pathological conditions, the balancing act that this cytokine plays in the mediation of MSC derived therapeutic activities is subject of intense investigation.

\section{Vascular Endothelial Growth Factor (VEGF)}

VEGF was one of the first described soluble angiogenesis stimulation factors [119]. This naturally occurring glycoprotein, which acts as a growth factor for endothelial cells, is produced by a variety of tissues in response to reduced oxygen tension, whose transcription is mediated in part by activation of the HIF-1 [120]. The essential role of VEGF in angiogenesis is exemplified by numerous studies demonstrating that blockade of this protein is therapeutic in angiogenesis-mediated diseases such as neoplasia and wet macular degeneration [121,122]. Conversely, administration of VEGF protein or DNA plasmid induces angiogenesis in animal models and in clinical trials [123,124]. Unfortunately, clinical use of VEGF for treatment of ischemic conditions has not met the required endpoints in Phase III clinical trials, in part due to poor regulation of VEGF-induced angiogenesis. In contrast, MSC expression of VEGF appears to be tightly regulated based on physiological need, and may represent a superior means of inducing therapeutic angiogenesis [125].

The role of VEGF in MSC-mediated angiogenesis was initially described in studies of bone marrow MSC administration into ischemic myocardium in animal models of heart failure. Stimulation of angiogenesis and endothelial cell proliferation was associated with MSC expression of VEGF in both small and large animal studies [126,127]. The superior effect of MSC administration in heart failure models, compared to administration of VEGF alone was demonstrated in subsequent studies [128]. Suggesting causative effects of VEGF in angiogenesis are studies showing that blockade of VEGF blocks MSC-induced angiogenesis in several animal models [129,130]. Furthermore, VEGF works as anti-apoptotic molecule suppressing p53-mediated apoptosis by activation of FAK (focal adhesion kinase), and also by promoting Bcl-2 and A1 [131,132]; clinical response to cell-based intervention has been associated with increases in serum VEGF levels [133].

\section{Tumor necrosis factor-stimulated gene-6 (TSG-6)}

TSG-6 is a 35 kDa glycoprotein which was originally discovered in the synovial fluids of patients with arthritis and serum of patients with inflammatory diseases [134]. Physiologically, it appears that one of the functions of TSG-6 is to counteract inflammatory effects of TNF-a and IL-1 [135]. Relating to MSC, original studies by Prockop et al. examined soluble mediators that may be responsible for regenerative effects of intravenously administered MSC in an animal infarct model. Cell tracking studies revealed that the majority of administered MSC lodged into the lung, however, potent post-infarct regeneration was observed. Using microarray analysis, it was found that TSG-6 was one of the most highly upregulated transcripts in lung-lodged MSC. Interestingly, silencing of TSG- 6 in the administered MSC resulted in loss of therapeutic activity, whereas, administration of exogenous TSG- 6 resulted in replication of therapeutic activity [42]. MSC therapeutic activities in other animal models of disease was observed to be dependent on TSG-6, including cerebral ischemia [136], diabetes type 1 [137], peritoneal adhesions [138,139], and experimental autoimmune encephalomyelitis (EAE) [140].

\section{Prostaglandin E2 (PGE2)}

PGE2 is a $352 \mathrm{Da}$ molecule belongs to the prostanoid family of small molecules, and is a product of arachidonic acid metabolism by the cyclo-oxygenase family of enzymes. Immune suppressive activities of PGE2 have been well characterized by type 2 macrophages and immature dendritic cells as a means of feedback inhibition after immune activation [141]. Inhibition of T cell activation by myeloid suppressor cells is also induced by PGE2 in models of cancer and pregnancy [142-145]. Mechanistically, PGE-2 inhibits various immune cells including NK cells [146], granulocytes [147], dendritic cells [148], and Th1 cells [149]. Additionally, PGE2 has also been shown to directly induce differentiation of T-regs expressing FoxP3 from naive T cells [150].

One of the most potent demonstrations of the ability of MSC-derived PGE2 to alter disease pathology was a study by Nemeth et al., in which BM-MSC inhibited sepsis in the aggressive cecal-puncture ligation model. Protection from sepsis was associated with generation of 
IL-10 producing macrophages, whose differentiation was dependent on MSC-produced PGE-2 [151]. Subsequent studies have supported the pivotal role of MSC generated PGE-2 in mediation of anti-inflammatory activities. Zhang et al. demonstrated that MSC administration into a bacterial-induced model of liver failure resulted in protection from lethality. Protection was associated with generation of T-regs and increases in serum IL-10. The systemic administration of COX inhibitors abrogated the protective effect [152]. In models of $\mathrm{T}$ cell mediated immune pathology, MSC administration inhibited allogeneic cardiac allograft rejection. When blockade of PGE2 generation was accomplished by COX inhibition, graft rejection, mediated by Th1 cells was observed [153].

PGE2 thus appears to be one of the major mediators of MSC associated immune modulation, specifically by acting as a promoter of T-regs and inhibitor of inflammatory responses. This is somewhat paradoxical to observations that systemic administration of PGE2 at large concentrations is pro-inflammatory. These differences are explained in part by various affinity PGE2 receptors on target tissues, and illustrate the biological complexity of MSC activities.

PGE2 is produced in different concentrations by MSCs depending on the source. Amniotic membrane [154] and chorionic villi [12] MSC produced higher concentrations of PGE2 under in vitro culture conditions than bone marrow or cord derived MSC. This variable should be considered if beneficial effect of PGE2 is desired for clinical applications.

\section{Galectin 1 and 9}

Galectins are a family of proteins that share characteristic amino acid sequences and affinity for $\beta$-galactoside sugars, such as N-acetyllactosamine (Galß1-3GlcNAc or Gal $\beta 1$ 4GlcNAc), and have consecutive numbers [155]. Gieseke group [156] have shown that Galectin 1 plays an important role in the immonumodulatory capacity of MSC. They demonstrated that $\mathrm{T}$ cells regulation capacity was diminished significantly in galectin-1 knockdown cells compared to wild type because of partially restored proliferation of $\mathrm{CD}^{+}$and $\mathrm{CD}^{+} \mathrm{T}$ cells and that the release of TNF $\alpha$, IFN $\gamma$, IL-2 and IL-10 was modulated by galectin 1 .

MSC immunomodulation is also affected by galectin-9, which is highly induced by inflammatory stimuli intracellular and also in the conditioned medium. Galectin-9 knockdown cells lose an important portion of their T-Cell antiproliferative effect [80].

\section{MSC derived microvesicles}

Production of microvesicles by MSC has been reported to be associated with regenerative activities. Microvesicles are generated from budding of the cell membrane and are considered to be $50 \mathrm{~nm}-1000 \mu \mathrm{m}$ in size. One of the first descriptions of microvesicles as related to regenerative medicine was by Quesenberry's group who demonstrated that culture of injured adult tissue with bone marrow cells results in bone marrow differentiation into cells of similar lineage as the injured tissue, with the proclivity of differentiation being mediated by microvesicles released from the injured tissue [157]. Subsequent studies have shown that there is a bidirectional communication between injured tissue and cells with regenerative potential, in that various stem cells also release microvesicles [158]. Specific examples of the regenerative potential of microvesicles follow. Bruno et al. utilized a glycerolinduced SCID mouse model of acute kidney injury, in which human MSC derived microvesicles were administered intravenously. Protection from acute kidney injury was observed, which was correlated with transfer of human miRNA into tubular epithelial cells. Treatment of microvesicles with RNAse resulted in abrogation of protective effects. This study supported the concept that MSC exert a protective effect against cellular apoptosis through transfer of miRNA [159]. In another model of kidney injury, Gatti et al. administered human MSC derived microvesicles into a renal ischemia reperfusion model [160]. A dose-dependent inhibition of acute tubular necrosis was observed, which correlated with preservation of renal function. Similar to the previously described study, protection from kidney injury was dependent on functional miRNA since treatment with RNAse eliminated protective activity.

Previous studies have suggested that MSC conditioned media is capable of stimulation proliferation of endothelial cells in vitro, and angiogenesis in vivo. Although the involvement of angiogenic cytokines such as VEGF and HGF-1 was previously believed to be responsible for this effect, antibody-blocking was not able to achieve 100\% inhibition of angiogenesis. Zhang et al. studied microvesicles collected from hypoxia preconditioned MSC CM, and demonstrated that microvesicles can be internalized by umbilical cord endothelial cells and promote proliferation in a dose-dependent manner. Also, MSC microvesicles stimulate angiogenesis in a hind limb ischemia model [161].

Another therapeutic activity of microvesicles appears to be related to suppression of alveolar inflammation in models of acute lung injury. Previous studies have demonstrated that intravenous MSC administration protects animals from endotoxin induced lung injury). Zhu et al. showed a dose-dependent reduction in water leakage and neutrophilic infiltration into the lung when intrapulmonary administration of bone marrow derived MSC isolated microvesicles were used in a similar model [162]. Interestingly, neutralization of therapeutic activity was observed by blockade of keratinocyte growth factor using siRNA. 
Another important study by Islam et al. shows the capacity of MSC to deliver encapsulated mitochondria in lung epithelial cells treated with LPS, leading to the survival of the host cells [163].

Overall, these studies suggest that microvesicles play an important role in MSC associated paracrine therapeutic activities, which may complement activities associated with release of soluble proteins and small molecules by MSC.

\section{MSC derived exosomes}

Exosomes are nanoparticles $(40-100 \mathrm{~nm})$ in size that possess highly defined homogeneous characteristics [164]. Originally, thought to be a by-product of cell protein turnover [165], these nanoparticles are becoming appreciated as a critical means of intracellular communication in areas ranging from neurotransmission [166], to immune modulation [165], to infectious disease [167].

Compared with other secreted vesicles such as microvesicles (described above), exosomes have much better defined biophysical and biochemical properties, specifically, they have a diameter of $40-100 \mathrm{~nm}$ (with a density in sucrose of $1.13-1.19 \mathrm{~g} / \mathrm{ml}$, and can be sedimented at $100,000 \mathrm{~g}$ [164]. Their membranes are enriched in cholesterol, sphingomyelin and ceramide, and are known to contain lipid rafts. Exosomes were originally discovered as a means of exportation of the transferrin receptor during sheep reticulocyte maturation [168]. In recent years an explosion of interest in exosomes has occurred, with a wide variety of cells being reported to secrete these nanoparticles ranging from $\mathrm{T}$ cells $[169,170]$, B cells [171,172], dendritic cells [173,174], tumor cells $[175,176]$, neurons $[177,178]$, oligodendrocytes [179], and placental cells [180]. Additionally, there is evidence that immune escape of the "fetal allograft" is associated with exosomes [181].

While MSC have been previously demonstrated to exert therapeutic effects in animal models of cardiac infarction, Lai et al. asked whether MSC-derived exosomes exert similar effects. They reported that MSC cultures generate phospholipid containing vesicles consisting of cholesterol, sphingomyelin, and phosphatidylcholine. These vesicles were believed to be exosomes based on coimmunoprecipitating with exosome-associated proteins, such as CD81, CD9, and Alix. These particles were purified as a homogeneous population of particles with a hydrodynamic radius of 55-65 $\mathrm{nm}$ by size-exclusion fractionation on a HPLC. It was found that administration of these particles, which resembled exosomes biochemically, to animal cardiac infarct models resulted in reduction of infarct size and improved heart function [162]. Mechanistically, the effects of MSC-derived exosomes on cardiac infarct appear to be mediated by increasing levels of ATP and NADH in cardiomyocytes, as well as decreasing oxidative stress and increased phosphorylated-Akt and phosphorylated-GSK$3 \beta$ [182].

In addition to protection from ischemia reperfusion injury, MSC functions such as inhibition of fibrotic injury have also been shown to be mediated by MSC-derived exosomes. Li et al. utilized the carbon tetrachloride model of fibrotic liver injury to demonstrate that administration of MSC-derived exosomes inhibited collagen deposition and preserved liver function in a manner similar to administration of MSCs themselves [183].

Mechanistically, the regenerative activities of MSCderived exosomes are a subject of ongoing investigation. Some studies suggest miRNA transfer by MSC-derived exosomes mediates various therapeutic effects [184], in a manner similar to microvesicles. Other studies suggest the involvement of exosome associated proteins such as lactadherin, or galectins, which are known to possess anti-inflammatory functions [185].

\section{Conclusions}

MSCs are rapidly emerging as a clinically-viable cell therapy, with numerous trials ongoing, and registration for marketing approval in several jurisdictions. The paradigm shift that MSCs activities are mediated by secreted factors as opposed to the previous notion of differentiation into injured tissue offers numerous possibilities for therapeutic development based on MSC secreted products. Current investigations at replicating in vitro the optimal environment for MSC production of therapeutic factors will lead to development of therapies utilizing MSC secreted factors which will alleviate the need for administration of cells.

\section{Competing interests}

The authors declare that they have no competing interests.

\section{Authors' contributions}

MM and NHR jointly conceived and contributed equally to the conception and preparation of the manuscript. KSR contributed throughout the preparation and edited the manuscript. All authors read and approved the final manuscript.

\section{Acknowledgements}

The authors wish to thank Ms. Rita Giovanni for her contribution to the artwork and Medistem Panama and SNI of SENACYT Panama for partial financial support.

\section{Author details}

'Department of Biotechnology, Acharya Nagarjuna University, Guntur, India. ${ }^{2}$ INDICASAT-AIP, City of Knowledge, Republic of Panama. ${ }^{3}$ MediStem Panama Inc., City of Knowledge, Republic of Panama.

Received: 28 June 2014 Accepted: 10 September 2014

Published online: 11 October 2014

\section{References}

1. Prockop DJ: Marrow stromal cells as stem cells for nonhematopoietic tissues. Science 1997, 276(5309):71-74.

2. Friedenstein AJ, Petrakova KV, Kurolesova AI, Frolova GP: Heterotopic transplants of bone marrow. Transplantation 1968, 6(2):230-247. 
3. Zannettino ACW, Paton S, Arthur A, Khor F, Itescu S, Gimble JM, Gronthos S: Multipotential human adipose-derived stromal stem cells exhibit a perivascular phenotype in vitro and in vivo. J Cell Physiol 2008, 214(2):413-421.

4. Hoogduijn MJ, Crop MJ, Peeters AMA, Van Osch GJV, Balk AHM, ljzermans JNM, Baan CC: Human heart, spleen, and perirenal fat-derived mesenchymal stem cells have immunomodulatory capacities. Stem Cells Dev 2007, 16(4):597-604.

5. Chao KC, Chao KF, Fu YS, Liu SH: Islet-like clusters derived from mesenchymal stem cells in Wharton's Jelly of the human umbilical cord for transplantation to control type 1 diabetes. PloS one 2008, 3(1):e1451.

6. Jo YY, Lee HJ, Kook SY, Choung HW, Park JY, Chung JH, Choung PH: Isolation and characterization of postnatal stem cells from human dental tissues. Tissue Eng 2007, 13(4):767-773.

7. He Q, Wan C, Li G: Concise review: multipotent mesenchymal stromal cells in blood. Stem cells (Dayton, Ohio) 2007, 25(1):69-77.

8. Oh W, Kim DS, Yang YS, Lee JK: Immunological properties of umbilical cord blood-derived mesenchymal stromal cells. Cellular Immunol 2008, 251(2):116-123.

9. Meng $X$, Ichim TE, Zhong J, Rogers A, Yin Z, Jackson J, Riordan NH: Endometrial regenerative cells: a novel stem cell population. J Trans/ Med 2007, 5:57.

10. Hida N, Nishiyama N, Miyoshi S, Kira S, Segawa K, Uyama T, Umezawa A: Novel cardiac precursor-like cells from human menstrual blood-derived mesenchymal cells. Stem cells 2008, 26(7):1695-1704

11. Patel AN, Park E, Kuzman M, Benetti F, Silva FJ, Allickson JG: Multipotent menstrual blood stromal stem cells: isolation, characterization, and differentiation. Cell transplant 2008, 17(3):303-311.

12. Yang ZX, Han Z-B, Ji YR, Wang YW, Liang L, Chi Y, Han ZC: CD106 identifies a subpopulation of mesenchymal stem cells with unique immunomodulatory properties. PloS one 2013, 8(3):e59354

13. Pittenger MF, Martin BJ: Mesenchymal stem cells and their potential as cardiac therapeutics. Circ Res 2004, 95(1):9-20.

14. Sugiyama $T$, Kohara $H$, Noda M, Nagasawa T: Maintenance of the hematopoietic stem cell pool by CXCL12-CXCR4 chemokine signaling in bone marrow stromal cell niches. Immunity 2006, 25(6):977-988.

15. Anthony BA, Link DC: Regulation of hematopoietic stem cells by bone marrow stromal cells. Trends Immunol 2014, 35(1):32-37.

16. Greenbaum A, Hsu YMS, Day RB, Schuettpelz LG, Christopher MJ, Borgerding JN, Link DC: CXCL12 in early mesenchymal progenitors is required for haematopoietic stem-cell maintenance. Nature 2013, 495(7440):227-230

17. Lazarus HM, Haynesworth SE, Gerson SL, Rosenthal NS, Caplan Al: Ex vivo expansion and subsequent infusion of human bone marrow-derived stromal progenitor cells (mesenchymal progenitor cells): implications for therapeutic use. Bone Marrow Transplant 1995, 16(4):557-564.

18. Koç ON, Gerson SL, Cooper BW, Dyhouse SM, Haynesworth SE, Caplan Al, Lazarus HM: Rapid hematopoietic recovery after coinfusion of autologousblood stem cells and culture-expanded marrow mesenchymal stem cells in advanced breast cancer patients receiving high-dose chemotherapy. J Clin Oncol 2000, 18(2):307-316.

19. Zhou Y, Yuan J, Zhou B, Lee AJ, Lee AJ, Ghawji M, Yoo TJ: The therapeutic efficacy of human adipose tissue-derived mesenchymal stem cells on experimental autoimmune hearing loss in mice. Immunology 2011 133(1):133-140

20. Kavanagh $\mathrm{H}$, Mahon BP: Allogeneic mesenchymal stem cells prevent allergic airway inflammation by inducing murine regulatory $T$ cells. Allergy 2011, 66(4):523-531.

21. Zanone MM, Favaro E, Miceli I, Grassi G, Camussi E, Caorsi C, Camussi G: Human mesenchymal stem cells modulate cellular immune response to islet antigen glutamic acid decarboxylase in type 1 diabetes. $J$ Clin Endocrinol Metab 2010, 95(8):3788-3797.

22. Rafei M, Birman E, Forner K, Galipeau J: Allogeneic mesenchymal stem cells for treatment of experimental autoimmune encephalomyelitis. Mol Ther 2009, 17(10):1799-1803.

23. Ding Y, Bushell A, Wood KJ: Mesenchymal stem-cell immunosuppressive capabilities: therapeutic implications in islet transplantation. Transplantation 2010, 89(3):270-273.

24. González MA, Gonzalez-Rey E, Rico L, Büscher D, Delgado M: Treatment of experimental arthritis by inducing immune tolerance with human adipose-derived mesenchymal stem cells. Arthritis Rheum 2009, 60(4):1006-1019.

25. González MA, Gonzalez-Rey E, Rico L, Büscher D, Delgado M: Adiposederived mesenchymal stem cells alleviate experimental colitis by inhibiting inflammatory and autoimmune responses. Gastroenterology 2009, 136(3):978-989.

26. Ryan JM, Barry FP, Murphy JM, Mahon BP: Mesenchymal stem cells avoid allogeneic rejection. J Inflamm (London, England) 2005, 2(8):11.

27. Kim SJ, Moon GJ, Chang WH, Kim Y-H, Bang OY: Intravenous transplantation of mesenchymal stem cells preconditioned with early phase stroke serum: current evidence and study protocol for a randomized trial. Trials 2013, 14(1):317-328.

28. Lee JS, Hong JM, Moon GJ, Lee PH, Ahn YH, Bang OY: Adipose-derived mesenchymal stem cells alleviate experimental colitis by inhibiting inflammatory and autoimmune responses. Stem cells (Dayton, Ohio) 2010, 28:1099-1106

29. Bang OY, Lee JS, Lee PH, Lee G: Autologous mesenchymal stem cell transplantation in stroke patients. Annals of neurolog 2005, 57(6):874-882

30. Bhasin A, Srivastava MVP, Mohanty S, Bhatia R, Kumaran SS, Bose S: Stem cell therapy: a clinical trial of stroke. Clin neurol neurosurgery Stem cells (Dayton, Ohio) 2010, 115(7):1003-1008.

31. Bartunek J, Behfar A, Dolatabadi D, Vanderheyden M, Ostojic M, Dens J, Terzic A: Cardiopoietic stem cell therapy in heart failure: the C-CURE (Cardiopoietic stem Cell therapy in heart failure) multicenter randomized trial with lineage-specified biologics. J American Coll Cardiol 2013, 61(23):2329-2338.

32. Yang Z, Zhang F, Ma W, Chen B, Zhou F, Xu Z, Zhang Y: A novel approach to transplanting bone marrow stem cells to repair human myocardial infarction: delivery via a noninfarct-relative artery. Cardiovascr Ther 2010, 28(6):380-385

33. Weiss DJ, Casaburi R, Flannery R, Leroux-Williams M, Tashkin DP: A placebocontrolled, randomized trial of mesenchymal stem cells in COPD. Chest 2013, 143(6):1590-1598.

34. Shi M, Zhang Z, Xu R, Lin H, Fu J, Zou Z, Wang FS: Human mesenchymal stem cell transfusion is safe and improves liver function in acute-onchronic liver failure patients. Stem Cells Transl Med 2012, 1(10):725-731.

35. Horwitz EM, Gordon PL, Koo WKK, Marx JC, Neel MD, McNall RY, Hofmann T: Isolated allogeneic bone marrow-derived mesenchymal cells engraft and stimulate growth in children with osteogenesis imperfecta: Implications for cell therapy of bone. Proc Natl Acad Sci USA 2002, 99(13):8932-8937.

36. Koç ON, Day J, Nieder M, Gerson SL, Lazarus HM, Krivit W: Allogeneic mesenchymal stem cell infusion for treatment of metachromatic leukodystrophy (MLD) and Hurler syndrome (MPS-IH). Bone Marrow Transplant 2002, 30(4):215-222.

37. Ichim TE, Alexandrescu DT, Solano F, Lara F, Campion RDN, Paris E, Riordan $\mathrm{NH}$ : Mesenchymal stem cells as anti-inflammatories: implications for treatment of Duchenne muscular dystrophy. Cell Immunol 2010, 260(2):75-82.

38. Murry $C E$, Soonpaa $M H$, Reinecke $H$, Nakajima $H$, Nakajima $H O$, Rubart $M$, Field LJ: Haematopoietic stem cells do not transdifferentiate into cardiac myocytes in myocardial infarcts. Nature 2004, 428(6983):664-668.

39. Wang C, Cheng L, Xu H, Liu Z: Towards whole-body imaging at the single cell level using ultra-sensitive stem cell labeling with oligo-arginine modified upconversion nanoparticles. Biomaterials 2012, 33(19):4872-4881.

40. Gnecchi M, He H, Liang OD, Melo LG, Morello F, Mu H, Dzau VJ: Paracrine action accounts for marked protection of ischemic heart by Aktmodified mesenchymal stem cells. Nat Med 2005, 11(4):367-368.

41. Gnecchi M, He H, Noiseux N, Liang OD, Zhang L, Morello F, Dzau VJ: Evidence supporting paracrine hypothesis for Akt-modified mesenchymal stem cell-mediated cardiac protection and functional improvement. FASEB 2006, 20(6):661-669.

42. Lee RH, Pulin AA, Seo MJ, Kota DJ, Ylostalo J, Larson BL, Prockop DJ: Intravenous hMSCs improve myocardial infarction in mice because cells embolized in lung are activated to secrete the anti-inflammatory protein TSG-6. Cell Stem Cell 2009, 5(1):54-63.

43. Shabbir A, Zisa D, Suzuki G, Lee T: Heart failure therapy mediated by the trophic activities of bone marrow mesenchymal stem cells: a noninvasive therapeutic regimen. Am J Physiol Heart Circ Physiol 2009, 296(6):H1888-H1897. 
44. Yang CC, Shih YH, Ko MH, Hsu SY, Cheng H, Fu YS: Transplantation of human umbilical mesenchymal stem cells from Wharton's jelly after complete transection of the rat spinal cord. PloS one 2008, 3(10):e3336

45. Song M, Heo J, Chun JY, Bae HS, Kang JW, Kang H, Choo MS: The paracrine effects of mesenchymal stem cells stimulate the regeneration capacity of endogenous stem cells in the repair of a bladder-outlet-obstructioninduced overactive bladder. Stem Cells Dev 2014, 23(6):654-663.

46. Ahluwalia A, Tarnawski AS: Critical role of hypoxia sensor - HIF-1a in VEGF gene activation. Implications for angiogenesis and tissue injury healing. Curr Med Chem 2012, 19(1):90-97.

47. Imtiyaz HZ, Simon MC: Hypoxia-inducible factors as essential regulators of inflammation. Curr Top Microbiol Immunol 2010, 345:105-120.

48. Hawkins KE, Sharp TV, McKay TR: The role of hypoxia in stem cell potency and differentiation. Regen Med 2013, 8(6):771-782.

49. Berniakovich I, Giorgio M: Low oxygen tension maintains multipotency, whereas normoxia increases differentiation of mouse bone marrow stromal cells. Int J Mol Sci 2013, 14(1):2119-2134.

50. Youn SW, Lee SW, Lee J, Jeong HK, Suh JW, Yoon CH, Kim HS: COMP-Ang1 stimulates HIF-1a-mediated SDF-1 overexpression and recovers ischemic injury through BM-derived progenitor cell recruitment. Blood 2011, 117:4376-4386.

51. Ceradini DJ, Kulkarni AR, Callaghan MJ, Tepper OM, Bastidas N, Kleinman ME, Gurtner GC: Progenitor cell trafficking is regulated by hypoxic gradients through HIF-1 induction of SDF-1. Nat Med 2004, 10(8):858-864.

52. Crisostomo PR, Wang Y, Markel TA, Wang M, Lahm T, Meldrum DR: Human mesenchymal stem cells stimulated by TNF-alpha, LPS, or hypoxia produce growth factors by an NF kappa B- but not JNK-dependent mechanism. Am J Physiol Cell Physiol 2008, 294(3):C675-C682. doi:10.1152/ajpcell.00437.2007.

53. Rasmussen JG, Frøbert O, Pilgaard L, Kastrup J, Simonsen U, Zachar V, Fink T: Prolonged hypoxic culture and trypsinization increase the proangiogenic potential of human adipose tissue-derived stem cells. Cytotherapy 2011, 13(3):318-328.

54. Yust-Katz S, Fisher-Shoval Y, Barhum Y, Ben-Zur T, Barzilay R, Lev N, Offen D: Placental mesenchymal stromal cells induced into neurotrophic factorproducing cells protect neuronal cells from hypoxia and oxidative stress. Cytotherapy 2012, 14(1):45-55.

55. lida K, Takeda-Kawaguchi T, Tezuka Y, Kunisada T, Shibata T, Tezuka K: Hypoxia enhances colony formation and proliferation but inhibits differentiation of human dental pulp cells. Archi Oral Biol 2010, 55(9):648-654

56. Efimenko A, Starostina E, Kalinina N, Stolzing A: Angiogenic properties of aged adipose derived mesenchymal stem cells after hypoxic conditioning. J Transl Med 2011, 9(1):10.

57. Chang CP, Chio CC, Cheong CU, Chao CM, Cheng BC, Lin MT: Hypoxic preconditioning enhances the therapeutic potential of the secretome from cultured human mesenchymal stem cells in experimental traumatic brain injury. Clin Sci (Lond) 2013, 124(3):165-176.

58. Yu J, Yin S, Zhang W, Gao F, Liu Y, Chen Z, Zheng S: Hypoxia preconditioned bone marrow mesenchymal stem cells promoted liver regeneration in a rat massive hepatectomy model. Stem Cell Res Ther 2013, 4(4):83.

59. Li JH, Zhang N, Wang JA: Improved anti-apoptotic and anti-remodeling potency of bone marrow mesenchymal stem cells by anoxic preconditioning in diabetic cardiomyopathy. J Endocrinol Invest 2008, 31(2):103-110.

60. Haque N, Rahman MT, Abu Kasim NH, Alabsi AM: Hypoxic culture conditions as a solution for mesenchymal stem cell based regenerative therapy. Scientific World Journal 2013 Artic 2013, (12). eCollection.

61. Le Blanc K, Frassoni F, Ball L, Locatelli F, Roelofs H, Lewis I, Ringdén O: Mesenchymal stem cells for treatment of steroid-resistant, severe, acute graft-versus-host disease: a phase II study. Lancet 2008, 371(9624):1579-1586.

62. Ning $H$, Yang $F$, Jiang $M, H u L$, Feng $K$, Zhang J, Chen $H$ : The correlation between cotransplantation of mesenchymal stem cells and higher recurrence rate in hematologic malignancy patients: outcome of a pilot clinical study. Leukemia 2008, 22(2):593-599.

63. Ball L, Bredius R, Lankester A, Schweizer J, van den Heuvel-Eibrink M, Escher $H$, Egeler M: Third party mesenchymal stromal cell infusions fail to induce tissue repair despite successful control of severe grade IV acute graftversus-host disease in a child with juvenile myelo-monocytic leukemia. Leukemia 2008, 22(6):1256-1257.
64. Ringdén O, Uzunel M, Rasmusson I, Remberger M, Sundberg B, Lönnies $\mathrm{H}_{\text {, }}$ Le Blanc K: Mesenchymal stem cells for treatment of therapy-resistant graft-versus-host disease. Transplantation 2006, 81(10):1390-1397.

65. Le Blanc K, Rasmusson I, Sundberg B, Götherström C, Hassan M, Uzunel M, Ringdén $O$ : Treatment of severe acute graft-versus-host disease with third party haploidentical mesenchymal stem cells. Lancet 2004 363(9419):1439-1441.

66. Müller I, Kordowich S, Holzwarth C, Isensee G, Lang P, Neunhoeffer F, Handgretinger R: Application of multipotent mesenchymal stromal cells in pediatric patients following allogeneic stem cell transplantation. Blood Cells, Mol Dis 2008, 40(1):25-32.

67. Roemeling-Van Rhijn M, Mensah FKF, Korevaar SS, Leijs MJC, Van Osch GJVM, IJzermans JNM, Hoogduijn MJ: Effects of hypoxia on the immunomodulatory properties of adipose tissue-derived mesenchymal stem cells. Front Immunol 2013, 4(203):8.

68. English K, Tonlorenzi R, Cossu G, Wood KJ: Mesoangioblasts suppress T cell proliferation through IDO and PGE-2-dependent pathways. Stem Cells Dev 2013, 22(3):512-523.

69. Engela AU, Baan CC, Peeters AM, Weimar W, Hoogduijn MJ: Interaction between adipose-tissue derived mesenchymal stem cells and regulatory T cells. Cell Transplant 2013, 22(1):41-54.

70. Jui HY, Lin CH, Hsu WT, Liu YR, Hsu RB, Chiang BL, Lee CM: Autologous mesenchymal stem cells prevent transplant arteriosclerosis by enhancing local expression of interleukin-10, interferon- $\gamma$, and indoleamine 2,3-dioxygenase. Cell Transplant 2012, 21(5):971-984.

71. Huang WH, Chen HL, Huang PH, Yew TL, Lin MW, Lin SJ, Hung SC: Hypoxic mesenchymal stem cells engraft and ameliorate limb ischaemia in allogeneic recipients. Cardiovasc Res 2014, 101(2):266-276.

72. Skurkovich B, Skurkovich S: Anti-interferon-gamma antibodies in the treatment of autoimmune diseases. Curr Opin Mol Ther 2003, 5(1):52-57.

73. Rong LJ, Chi Y, Yang SG, Chen DD, Chen F, Xu SX, Han ZC: [Effects of interferon- $\gamma$ on biological characteristics and immunomodulatory property of human umbilical cord-derived mesenchymal stem cells]. Zhongguo shi yan xue ye xue za zhi $=J$ Exp hematology / Chin Assoc Pathophysiol 2012, 20(2):421-426.

74. Kang JW, Koo HC, Hwang SY, Kang SK, Ra JC, Lee MH, Park YH: Immunomodulatory effects of human amniotic membrane-derived mesenchymal stem cells. J Vet Sci 2012, 13(1):23-31.

75. Lin W, Oh SKW, Choo ABH, George AJT: Activated T cells modulate immunosuppression by embryonic-and bone marrow-derived mesenchymal stromal cells through a feedback mechanism. Cytotherapy 2012, 14(3):274-284.

76. Croitoru-Lamoury J, Lamoury FMJ, Caristo M, Suzuki K, Walker D, Takikawa $O$, Brew $B J$ : Interferon- $\gamma$ regulates the proliferation and differentiation of mesenchymal stem cells via activation of indoleamine 2,3 dioxygenase (IDO). PloS one 2011, 6(2):e14698. doi:10.1371/journal.pone.0014698.

77. Tu Z, Li Q, Bu H, Lin F: Mesenchymal stem cells inhibit complement activation by secreting factor H. Stem Cells Dev 2010, 19(11):1803-1809.

78. Ryan JM, Barry F, Murphy JM, Mahon BP: Interferon-gamma does not break, but promotes the immunosuppressive capacity of adult human mesenchymal stem cells. Clin Exp Immunol 2007, 149(2):353-363.

79. Noone C, Kihm A, English K, O'Dea S, Mahon BP: IFN-gamma stimulated human umbilical-tissue derived cells potently suppress NK activation and resist NK mediated cytotoxicity in vitro. Stem Cells Dev 2013, 15(22):3003-3014.

80. Gieseke F, Kruchen A, Tzaribachev N, Bentzien F, Dominici M, Müller I: Proinflammatory stimuli induce galectin- 9 in human mesenchymal stromal cells to suppress T-cell proliferation. Europ J Immunol 2013, 43(10):2741-2749.

81. Kwon YW, Heo SC, Jeong GO, Yoon JW, Mo WM, Lee MJ, Kim JH: Tumor necrosis factor-a-activated mesenchymal stem cells promote endothelial progenitor cell homing and angiogenesis. Biochim Biophys Acta 2013, 1832(12):2136-2144.

82. Lu Z, Wang G, Dunstan CR, Chen Y, Lu WYR, Davies B, Zreiqat H: Activation and promotion of adipose stem cells by tumour necrosis factor-alpha preconditioning for bone regeneration. J Cell Physiol 2013 228(8):1737-1744

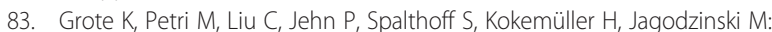
Toll-like receptor 2/6-dependent stimulation of mesenchymal stem cells promotes angiogenesis by paracrine factors. Europ Cells Mater 2013, 26:66-79. discussion 79. 
84. Bessout R, Sémont A, Demarquay C, Charcosset A, Benderitter M, Mathieu N: Mesenchymal stem cell therapy induces glucocorticoid synthesis in colonic mucosa and suppresses radiation-activated T cells: new insights into MSC immunomodulation. Mucosal Immunol 2014, 7(3):656-669.

85. Bartosh TJ, Ylöstalo JH, Mohammadipoor A, Bazhanov N, Coble K, Claypool K, Prockop DJ: Aggregation of human mesenchymal stromal cells (MSCs) into 3D spheroids enhances their antiinflammatory properties. Proc Natl Acad Sci USA 2010, 107(31):13724-13729.

86. Ylöstalo JH, Bartosh TJ, Coble K, Prockop DJ: Human mesenchymal stem/ stromal cells cultured as spheroids are self-activated to produce prostaglandin E2 that directs stimulated macrophages into an anti-inflammatory phenotype. Stem Cells 2012, 30(10):2283-2296.

87. Bartosh TJ, Ylöstalo JH, Bazhanov N, Kuhlman J, Prockop DJ: Dynamic compaction of human mesenchymal stem/precursor cells into spheres self-activates caspase-dependent IL1 signaling to enhance secretion of modulators of inflammation and immunity (PGE2, TSG6, and STC1). Stem Cells 2013, 31(11):2443-2456.

88. Frith JE, Thomson B, Genever PG: Dynamic three-dimensional culture methods enhance mesenchymal stem cell properties and increase therapeutic potential. Tissue Eng Part C Methods 2010, 16(4):735-749.

89. Nakamura T: Structure and function of hepatocyte growth factor. Progr Growth Factor Res 1991, 3(1):67-85.

90. Lefebvre J, Ancot F, Leroy C, Muharram G, Lemiere A, Tulasne D: Met degradation: more than one stone to shoot a receptor down. FASEB J 2012, 26(4):1387-1399.

91. Roletto F, Galvani AP, Cristiani C, Valsasina B, Landonio A, Bertolero F: Basic fibroblast growth factor stimulates hepatocyte growth factor/scatter factor secretion by human mesenchymal cells. J Cell Physiol 1996, 166(1):105-111.

92. Wilson SE, Walker JW, Chwang EL, He YG: Hepatocyte growth factor, keratinocyte growth factor, their receptors, fibroblast growth factor receptor-2, and the cells of the cornea. Invest Ophthalmol Vis Sci 1993, 34(8):2544-2561

93. Watanabe S, Hirose M, Wang XE, Maehiro K, Murai T, Kobayashi O, Sato N: Hepatocyte growth factor accelerates the wound repair of cultured gastric mucosal cells. Biochem Biophys Res Commun 1994, 199(3):1453-1460.

94. Pyun WB, Hahn W, Kim DS, Yoo WS, Lee SD, Won JH, Kim S: Naked DNA expressing two isoforms of hepatocyte growth factor induces collateral artery augmentation in a rabbit model of limb ischemia. Gene Ther 2010, 17(12):1442-1452.

95. Morishita R, Makino H, Aoki M, Hashiya N, Yamasaki K, Azuma J, Ogihara T: Phase I/lla clinical trial of therapeutic angiogenesis using hepatocyte growth factor gene transfer to treat critical limb ischemia. Arterioscler Thromb, Vasc Biol 2011, 31(3):713-720.

96. Shigematsu H, Yasuda K, Sasajima T, Takano T, Miyata T, Ohta T, Morishita R: Transfection of human HGF plasmid DNA improves limb salvage in Buerger's disease patients with critical limb ischemia. International Angiol 2011, 30(2):140-149.

97. Rutella S, Danese S, Leone G: Tolerogenic dendritic cells: cytokine modulation comes of age. Blood 2006, 108(5):1435-1440.

98. Benkhoucha M, Santiago-Raber ML, Schneiter G, Chofflon M, Funakoshi H, Nakamura T, Lalive PH: Hepatocyte growth factor inhibits CNS autoimmunity by inducing tolerogenic dendritic cells and CD25+ Foxp3+ regulatory T cells. Proc Natl Acad Sci USA 2010, 107(14):6424-6429.

99. Okunishi K, Dohi M, Fujio K, Nakagome K, Tabata Y, Okasora T, Yamamoto K: Hepatocyte growth factor significantly suppresses collagen-induced arthritis in mice. J Immunol 2011, 179(8):5504-5513.

100. Bai L, Lennon DP, Caplan Al, DeChant A, Hecker J, Kranso J, Miller RH: Hepatocyte growth factor mediates mesenchymal stem cell-induced recovery in multiple sclerosis models. Nat Neurosci 2012, 15(6):862-870

101. Lu S, Lu C, Han Q, Li J, Du Z, Liao L, Zhao RC: Adipose-derived mesenchymal stem cells protect PC12 cells from glutamate excitotoxicity-induced apoptosis by upregulation of XIAP through PI3-K/ Akt activation. Toxicology 2011, 279(1-3):189-195.

102. Yasuda K, Ozaki T, Saka Y, Yamamoto T, Gotoh M, Ito Y, Maruyama S: Autologous cell therapy for cisplatin-induced acute kidney injury by using non-expanded adipose tissue-derived cells. Cytotherapy 2012, 14(9):1089-1100.

103. Mishra L, Derynck R, Mishra B: Transforming growth factor-beta signaling in stem cells and cancer. Science 2005, 310(5745):68-71.
104. Verrecchia F, Mauviel A: Transforming growth factor-beta signaling through the Smad pathway: role in extracellular matrix gene expression and regulation. J Invest Dermatol 2002, 118(2):211-215.

105. Whiteside TL: What are regulatory T cells (Treg) regulating in cancer and why? Semin Cancer Biol 2012, 22(4):327-334.

106. Smith AL, Robin TP, Ford HL: Molecular pathways: targeting the TGF- pathway for cancer therapy. Clin Cancer Res 2012, 18(17):4514-4521.

107. Raghupathy R: Pregnancy: success and failure within the Th1/Th2/Th3 paradigm. Semin Immunol 2001, 13(4):219-227.

108. Ohta K, Yamagami S, Taylor AW, Streilein JW: IL-6 antagonizes TGF-beta and abolishes immune privilege in eyes with endotoxin-induced uveitis. Invest Ophthalmol Vis Sci 2000, 41(9):2591-2599.

109. Tompkins AB, Hutchinson P, De Kretser DM, Hedger MP: Characterization of lymphocytes in the adult rat testis by flow cytometry: effects of activin and transforming growth factor beta on lymphocyte subsets in vitro. Biol Reprod 1998, 58(4):943-951.

110. Gandhi R, Anderson DE, Weiner HL: Cutting Edge: Immature human dendritic cells express latency-associated peptide and inhibit $T$ cell activation in a TGF-beta-dependent manner. J Immunol 2007, 178(7):4017-4021.

111. Kushwah R, Wu J, Oliver JR, Jiang G, Zhang J, Siminovitch KA, Hu J: Uptake of apoptotic DC converts immature DC into tolerogenic DC that induce differentiation of Foxp3+ Treg. Eur J Immunol 2010, 40(4):1022-1035.

112. Romagnani S: Human Th17 cells. Arthritis rRes Ther 2008, 10(2):206.

113. Melief SM, Zwaginga JJ, Fibbe WE, Roelofs H: Adipose tissue-derived multipotent stromal cells have a higher immunomodulatory capacity than their bone marrow-derived counterparts. Stem Cells Transl Med 2013, 2(6):455-463.

114. Miguel M: Immunosuppressive properties of mesenchymal stem cells: advances and applications. Curr Mol Med 2012, 12(5):574-591.

115. Zhou C, Yang B, Tian Y, Jiao H, Zheng W, Wang J, Guan F: Immunomodulatory effect of human umbilical cord Wharton's jellyderived mesenchymal stem cells on lymphocytes. Cell Immunol 2011, 272(1):33-38.

116. Zhao ZG, Li WM, Chen ZC, You Y, Zou P: Immunosuppressive properties of mesenchymal stem cells derived from bone marrow of patients with chronic myeloid leukemia. Immunol Invest 2008, 37(7):726-739.

117. Yoo SW, Chang DY, Lee HS, Kim GH, Park JS, Ryu BY, Suh-Kim H: Immune following suppression mesenchymal stem cell transplantation in the ischemic brain is mediated by TGF- $\beta$. Neurobiol Dis 2013, 58:249-257.

118. Ye Z, Wang Y, Xie HY, Zheng SS: Immunosuppressive effects of rat mesenchymal stem cells: involvement of CD4 + CD25+ regulatory $T$ cells. Hepatobiliary Pancreat Dis Int 2008, 7(6):608-614.

119. Connolly DT: Vascular permeability factor: a unique regulator of blood vessel function. J Cell Biochem 1991, 47(3):219-223.

120. Razban V, Lotfi AS, Soleimani M, Ahmadi H, Massumi M, Khajeh S, Khoshdel A: HIF-1a overexpression induces angiogenesis in mesenchymal stem cells. Biores Open Access 2012, 1(4):174-183.

121. Semeraro F, Morescalchi F, Duse S, Parmeggiani F, Gambicorti E, Costagliola C: Aflibercept in wet AMD: specific role and optimal use. Drug Des, Devel Ther 2013, 7:711-722.

122. Chen $C T$, Hung MC: Beyond anti-VEGF: dual-targeting antiangiogenic and antiproliferative therapy. Am J Trans/ Res 2013, 5(4):393-403.

123. Mughal NA, Russell DA, Ponnambalam S, Homer-Vanniasinkam S: Gene therapy in the treatment of peripheral arterial disease. Br J Surg 2012, 99(1):6-15.

124. Chawla PS, Keelan MH, Kipshidze N: Angiogenesis for the treatment of vascular diseases. Int Angiol 1999, 18(3):185-192.

125. Kagiwada H, Yashiki T, Ohshima A, Tadokoro M, Nagaya N, Ohgushi H: Human mesenchymal stem cells as a stable source of VEGF-producing cells. J Tissue Eng Regen Med 2008, 2(4):184-189.

126. Tang YL, Zhao Q, Zhang YC, Cheng L, Liu M, Shi J, Phillips MI: Autologous mesenchymal stem cell transplantation induce VEGF and neovascularization in ischemic myocardium. Regul Pept 2004, 117(1):3-10

127. Halkos ME, Zhao ZQ, Kerendi F, Wang NP, Jiang R, Schmarkey LS, Vinten-Johansen J: Intravenous infusion of mesenchymal stem cells enhances regional perfusion and improves ventricular function in a porcine model of myocardial infarction. Basic Res Cardiol 2008, 103(6):525-536.

128. Shyu KG, Wang BW, Hung HF, Chang CC, Shih DTB: Mesenchymal stem cells are superior to angiogenic growth factor genes for improving 
myocardial performance in the mouse model of acute myocardial infarction. J Biomed Sci 2006, 13(1):47-58.

129. Luo $H$, Zhang $Y$, Zhang $Z$, Jin $Y$ : The protection of MSCs from apoptosis in nerve regeneration by TGF $\beta 1$ through reducing inflammation and promoting VEGF-dependent angiogenesis. Biomaterials 2012, 33(17):4277-4287.

130. Hayashi Y, Tsuji S, Tsujii M, Nishida T, Ishii S, lijima H, Kawano S: Topical transplantation of mesenchymal stem cells accelerates gastric ulcer healing in rats. Am J Physiol Gastrointest Liver Physiol 2008, 294(3):G778-G786.

131. Ilić D, Almeida EA, Schlaepfer DD, Dazin P, Aizawa S, Damsky CH: Extracellular matrix survival signals transduced by focal adhesion kinase suppress p53-mediated apoptosis. J Cell Biol 1998, 143(2):547-560.

132. Gerber HP, Dixit V, Ferrara N: Vascular endothelial growth factor induces expression of the antiapoptotic proteins $\mathrm{BCl}-2$ and $\mathrm{A} 1$ in vascular endothelial cells. J Biol Chem 1998, 273(21):13313-13316.

133. Tachi Y, Fukui D, Wada Y, Koshikawa M, Shimodaira S, Ikeda U, Amano J: Changes in angiogenesis-related factors in serum following autologous bone marrow cell implantation for severe limb ischemia. Expert Opin Biol Ther 2008, 8(6):705-712.

134. Wisniewski HG, Vilcek J: TSG-6: an IL-1/TNF-inducible protein with antiinflammatory activity. Cytokine Growth Factor Rev 1997, 8(2):143-156.

135. Wisniewski H-G, Vilcek J: Cytokine-induced gene expression at the crossroads of innate immunity, inflammation and fertility: TSG-6 and PTX3/TSG-14. Cytokine Growth Factor Rev 2004, 15(2-3):129-146.

136. Lin QM, Zhao S, Zhou LL, Fang XS, Fu Y, Huang ZT: Mesenchymal stem cells transplantation suppresses inflammatory responses in global cerebral ischemia: contribution of TNF-a-induced protein 6 . Acta Pharmacol Sin 2013, 34(6):784-792.

137. Kota DJ, Wiggins LL, Yoon N, Lee RH: TSG-6 produced by hMSCs delays the onset of autoimmune diabetes by suppressing Th1 development and enhancing tolerogenicity. Diabetes 2013, 62(6):2048-2058.

138. Wang N, Shao Y, Mei Y, Zhang L, Li Q, Li D, Chen X: Novel mechanism for mesenchymal stem cells in attenuating peritoneal adhesion: accumulating in the lung and secreting tumor necrosis factor a-stimulating gene-6. Stem Cell Res Ther 2012, 3(6):51.

139. Wang N, Li Q, Zhang L, Lin H, Hu J, Li D, Chen X: Mesenchymal stem cells attenuate peritoneal injury through secretion of TSG-6. PLOS ONE 2012, 7(8):e43768

140. Fisher-Shoval Y, Barhum Y, Sadan O, Yust-Katz S, Ben-Zur T, Lev N, Offen D: Transplantation of placenta-derived mesenchymal stem cells in the EAE mouse model of MS. J Mol Neurosci 2012, 48(1):176-184.

141. Lee JJ, Takei M, Hori S, Inoue $Y$, Harada Y, Tanosaki R, Kakizoe T: The role of PGE(2) in the differentiation of dendritic cells: how do dendritic cells influence T-cell polarization and chemokine receptor expression? Stem Cells 2002, 20(5):448-459.

142. Zhang Y, Liu Q, Zhang M, Yu Y, Liu X, Cao X: Fas signal promotes lung cancer growth by recruiting myeloid-derived suppressor cells via cancer cell-derived PGE2. J Immunol 2009, 182(6):3801-3808.

143. Eruslanov E, Daurkin I, Ortiz J, Vieweg J, Kusmartsev S: Pivotal Advance: Tumor-mediated induction of myeloid-derived suppressor cells and M2-polarized macrophages by altering intracellular PGE catabolism in myeloid cells. J leukoc Biol 2010, 88(5):839-848.

144. Eruslanov E, Daurkin I, Vieweg J, Daaka Y, Kusmartsev S: Aberrant PGE metabolism in bladder tumor microenvironment promotes immunosuppressive phenotype of tumor-infiltrating myeloid cells. Int immunopharmacol 2011, 11(7):848-855.

145. Obermajer N, Muthuswamy R, Lesnock J, Edwards RP, Kalinski P: Positive feedback between PGE2 and COX2 redirects the differentiation of human dendritic cells toward stable myeloid-derived suppressor cells. Blood 2011, 118(20):5498-5505.

146. Goto T, Herberman RB, Maluish A, Strong DM: Cyclic AMP as a mediator of prostaglandin E-induced suppression of human natural killer cell activity. J Immunol 1983, 130(3):1350-1355.

147. Smith RJ: Modulation of phagocytosis by and lysosomal enzyme secretion from guinea-pig neutrophils: effect of nonsteroid antiinflammatory agents and prostaglindins. J Pharmacol Exper Ther 1977, 200(3):647-657.

148. Kaliński P, Hilkens CM, Snijders A, Snijdewint FG, Kapsenberg ML: IL-12deficient dendritic cells, generated in the presence of prostaglandin E2, promote type 2 cytokine production in maturing human naive T helper cells. J Immunol 1997, 159(1):28-35.

149. Snijdewint FG, Kaliński P, Wierenga EA, Bos JD, Kapsenberg ML: Prostaglandin E2 differentially modulates cytokine secretion profiles of human T helper lymphocytes. J Immunol 1993, 150(12):5321-5329.

150. Baratelli F, Lin Y, Zhu L, Yang S-C, Heuzé-Vourc'h N, Zeng G, Dubinett SM: Prostaglandin E2 induces FOXP3 gene expression and T regulatory cell function in human CD4+ T cells. J Immunol 2005, 175(3):1483-1490.

151. Németh K, Leelahavanichkul A, Yuen PST, Mayer B, Parmelee A, Doi K, Mezey E: Bone marrow stromal cells attenuate sepsis via prostaglandin $E$ (2)-dependent reprogramming of host macrophages to increase their interleukin-10 production. Nat Med 2009, 15(1):42-49.

152. Zhang Y, Cai W, Huang Q, Gu Y, Shi Y, Huang J, Zhang Y: Mesenchymal stem cells alleviate bacteria-induced liver injury in mice by inducing regulatory dendritic cells. Hepatology 2013, 59(2):671-682.

153. Dhingra S, Li P, Huang XP, Guo J, Wu J, Mihic A, Li RK: Preserving prostaglandin E2 level prevents rejection of implanted allogeneic mesenchymal stem cells and restores postinfarction ventricular function. Circulation 2013, 128(11 Suppl 1):S69-S78.

154. Parolini O, Lombardi G, Cargnoni A, Rossi D, Arienti D, Ressel L, Poli A: Medium from amniotic mesenchymal tissue cells reduces progression of bleomycin-induced lung fibrosis. Cytotherapy 2012, 14(2):153-161.

155. Barondes SH, Cooper DN, Gitt MA, Leffler H: Galectins. Structure and function of a large family of animal lectins. J Biol Chem 1994, 269(33):20807-20810.

156. Gieseke F, Böhringer J, Bussolari R, Dominici M, Handgretinger R, Müller I: Human multipotent mesenchymal stromal cells use galectin-1 to inhibit immune effector cells. Blood 2010, 116(19):3770-3779.

157. Quesenberry PJ, Aliotta JM: The paradoxical dynamism of marrow stem cells: considerations of stem cells, niches, and microvesicles. Stem Cell Rev 2008, 4(3):137-147

158. Fierabracci A, Del Fattore A, Luciano R, Muraca M, Teti A, Muraca M: Recent advances in mesenchymal stem cell immunomodulation. The role of microvesicles. Cell transplantat 2013, [Epub ahead of print].

159. Bruno S, Grange C, Deregibus MC, Calogero RA, Saviozzi S, Collino F, Camussi G: Mesenchymal stem cell-derived microvesicles protect against acute tubular injury. J Am Soc Nephrol 2009, 20(5):1053-1067.

160. Gatti S, Bruno S, Deregibus MC, Sordi A, Cantaluppi V, Tetta C, Camussi G: Microvesicles derived from human adult mesenchymal stem cells protect against ischaemia-reperfusion-induced acute and chronic kidney injury. Nephrol Dial Transplant 2012, 26(5):1474-1483.

161. Zhang HC, Liu XB, Huang S, Bi XY, Wang HX, Xie LX, Guo ZK: Microvesicles derived from human umbilical cord mesenchymal stem cells stimulated by hypoxia promote angiogenesis both in vitro and in vivo. Stem Cells Dev 2012, 21(18):3289-3297.

162. Zhu YG, Feng XM, Abbott J, Fang XH, Hao Q, Monsel A, Lee JW: Human mesenchymal stem cell microvesicles for treatment of $E$. coli endotoxininduced acute lung injury in mice. Stem cells 2014, 32(1):116-125.

163. Islam MN, Das SR, Emin MT, Wei M, Sun L, Westphalen K, Bhattacharya J: Mitochondrial transfer from bone-marrow-derived stromal cells to pulmonary alveoli protects against acute lung injury. Nat Med 2012, 18(5):759-765.

164. Théry C, Ostrowski M, Segura E: Membrane vesicles as conveyors of immune responses. Nat Rev Immunol 2009, 9(8):581-593.

165. Ludwig AK, Giebel B: Exosomes: Small vesicles participating in intercellular communication. Int J Biochem Cell Biol 2012, 44(1):11-15.

166. Alvarez-Erviti L, Seow Y, Schapira AH, Gardiner C, Sargent IL, Wood MJA, Cooper JM: Lysosomal dysfunction increases exosome-mediated alpha-synuclein release and transmission. Neurobiol Dis 2011, 42(3):360-367.

167. Silverman JM, Reiner NE: Exosomes and other microvesicles in infection biology: organelles with unanticipated phenotypes. Cell Microbiol 2011, 13(1):1-9.

168. Pan BT, Johnstone RM: Fate of the transferrin receptor during maturation of sheep reticulocytes in vitro: selective externalization of the receptor. Cell 1983, 33(3):967-978.

169. Alonso R, Mazzeo C, Rodriguez MC, Marsh M, Fraile-Ramos A, Calvo V, Izquierdo M: Diacylglycerol kinase a regulates the formation and polarisation of mature multivesicular bodies involved in the secretion of Fas ligand-containing exosomes in T lymphocytes. Cell death Differ 2011, 18(7):1161-1173. 
170. Zhang H, Xie Y, Li W, Chibbar R, Xiong S, Xiang J: CD4(+) T cell-released exosomes inhibit CD8(+) cytotoxic T-lymphocyte responses and antitumor immunity. Cell Mol Immunol 2011, 8(1):23-30.

171. Mathews JA, Gibb DR, Chen BH, Scherle P, Conrad DH: CD23 Sheddase A disintegrin and metalloproteinase 10 (ADAM10) is also required for CD23 sorting into B cell-derived exosomes. J Biol Chem 2010, 285(48):37531-37541.

172. Buschow SI, Van Balkom BWM, Aalberts M, Heck AJR, Wauben M, Stoorvogel W: MHC class II-associated proteins in B-cell exosomes and potential functional implications for exosome biogenesis. Immunol Cell Biol 2010, 88(8):851-856.

173. Hwang I, Ki D: Receptor-mediated T cell absorption of antigen presenting cell-derived molecules. Front Biosci 2011, 16:411-421.

174. Viaud S, Ploix S, Lapierre V, Théry C, Commere PH, Tramalloni D, Chaput N: Updated technology to produce highly immunogenic dendritic cell-derived exosomes of clinical grade: a critical role of interferon- $\gamma$. J Immunother 2011, 34(1):65-75.

175. Clayton A, Al-Taei S, Webber J, Mason MD, Tabi Z: Cancer exosomes express $C D 39$ and $C D 73$, which suppress $T$ cells through adenosine production. J Immunol 2011, 187(2):676-683.

176. Battke C, Ruiss R, Welsch U, Wimberger P, Lang S, Jochum S, Zeidler R: Tumour exosomes inhibit binding of tumour-reactive antibodies to tumour cells and reduce ADCC. Cancer Immunol Immunother 2011, 60(5):639-648

177. Lachenal G, Pernet-Gallay K, Chivet M, Hemming FJ, Belly A, Bodon G, Sadoul R: Release of exosomes from differentiated neurons and its regulation by synaptic glutamatergic activity. Mol Cell Neurosci 2011, 46(2):409-418

178. Fauré J, Lachenal G, Court M, Hirrlinger J, Chatellard-Causse C, Blot B, Sadoul R: Exosomes are released by cultured cortical neurones. Mol Cell Neurosci 2006, 31(4):642-648.

179. Fitzner D, Schnaars M, Van Rossum D, Krishnamoorthy G, Dibaj P, Bakhti M, Simons M: Selective transfer of exosomes from oligodendrocytes to microglia by macropinocytosis. J Cell Sci 2011, 124(Pt 3):447-458.

180. Mincheva-Nilsson L, Baranov V: The role of placental exosomes in reproduction. Am J Reprod Immunol 2010, 63(6):520-533.

181. Mincheva-Nilsson L, Nagaeva O, Chen T, Stendahl U, Antsiferova J, Mogren I, Baranov V: Placenta-derived soluble MHC class I chain-related molecules down-regulate NKG2D receptor on peripheral blood mononuclear cells during human pregnancy: a possible novel immune escape mechanism for fetal survival. J Immunol 2006, 176(6):3585-3592.

182. Arslan F, Lai RC, Smeets MB, Akeroyd L, Choo A, Aguor ENE, De Kleijn DP: Mesenchymal stem cell-derived exosomes increase ATP levels, decrease oxidative stress and activate PI3K/Akt pathway to enhance myocardial viability and prevent adverse remodeling after myocardial ischemia/ reperfusion injury. Stem Cell Res 2013, 10(3):301-312.

183. Li T, Yan Y, Wang B, Qian H, Zhang X, Shen L, Xu W: Exosomes derived from human umbilical cord mesenchymal stem cells alleviate liver fibrosis. Stem Cells Dev 2013, 22(6):845-854.

184. Tomasoni S, Longaretti L, Rota C, Morigi M, Conti S, Gotti E, Benigni A: Transfer of growth factor receptor mRNA via exosomes unravels the regenerative effect of mesenchymal stem cells. Stem Cells Dev 2012, 22(5):772-780.

185. Raymond A, Ensslin MA, Shur BD: SED1/MFG-E8: a bi-motif protein that orchestrates diverse cellular interactions. J Cell Biochem 2009, 106(6):957-966.

doi:10.1186/s12967-014-0260-8

Cite this article as: Madrigal et al: A review of therapeutic effects of mesenchymal stem cell secretions and induction of secretory modification by different culture methods. Journal of Translational Medicine 2014 12:260.

\section{Submit your next manuscript to BioMed Central and take full advantage of:}

- Convenient online submission

- Thorough peer review

- No space constraints or color figure charges

- Immediate publication on acceptance

- Inclusion in PubMed, CAS, Scopus and Google Scholar

- Research which is freely available for redistribution

Submit your manuscript at www.biomedcentral.com/submit 